\title{
Effects of tungstate in neonatally streptozotocin-induced diabetic rats: mechanism leading to normalization of glycaemia
}

\author{
A . B arberà ${ }^{1}$, J . Fernàndez-A Ivarez ${ }^{2}$, A . Truc ${ }^{2}$, R . G omis ${ }^{2}$, J J . G uinovart ${ }^{1}$ \\ ${ }^{1} \mathrm{D}$ epartment of B iochemistry and M olecular B iology, U niversity of B arcelona, B arcelona, Spain \\ ${ }^{2}$ E ndocrinology and D iabetes U nit, School of M edicine, H ospital Clínic U niversitari de B arcelona, Barcelona, Spain
}

Summary The effects of oral administration of tungstate to an animal model of non-insulin-dependent diabetes mellitus (NIDDM), the neonatally streptozotocin-induced diabetic rat was studied. I slet insulin content and beta-cell mass were lowered in these animals. Furthermore, the islets lost their ability to release insulin in response to an increase in glucose concentration. H owever, the hepatic glucose metabolism in these diabetic animals before the treatment was not significantly altered with regard to glycogen content, or glucokinase or glycogen phosphorylase activities compared with healthy animals. On the other hand, the activation state of glycogen synthase was higher although the total activity was unchanged. $M$ oreover, a $20 \%$ increase in the concentrations of liver glucose 6-phosphate compared to their healthy siblings was observed. O ral administration of tungstate for 15 days normalized glycaemia in these diabetic animals ( 4.6 vs $7.8 \mathrm{mmol} / \mathrm{l}$ ). Tungstate administration was also able to normalize beta-cell insulin secretion in response to $16.7 \mathrm{mmol} / \mathrm{l}$ glucose stimulus, reaching values similar to those observed in healthy animals. Concomitantly, a partial recovery in the insulin content and in preproinsulin $\mathrm{mR} N \mathrm{~N}$ levels was found in the islets of treated animals, which was associated with an increase in the number of betacells in the pancreas ( 1.73 vs $0.86 \%$ ). The treatment did not change the liver parameters studied, except that it restored glucose 6-phosphate concentrations to healthy values. These data suggest that tungstate administration causes a normalization of glycaemia through the restoration of islet function. [D iabetologia (1997) 40: 143-149]

Keywords Tungstate, nSTZ-diabetic rats, islets, insulin, glycogen.
When adult rats injected with streptozotocin (STZdiabetic rats) were treated orally with tungstate a reduction in blood glucose levels and a normalization of hepatic glucose metabolism was observed [1]. Tungstate administration decreased glycaemia to levels similar to those observed in healthy animals, while

R eceived: 20 J une 1996 and in revised form: 220 ctober 1996

Corresponding author: Professor J.J. Guinovart, D epartment Bioquímica i Biologia Molecular, U niversitat de Barcelona, $M$ artí i Franquès, 1, E -08028 Barcelona, Spain

A bbreviations: STZ, Streptozotocin; nSTZ-diabetic rat, neonatally streptozotocin-injected rats; ST Z-diabetic rat, adult streptozotocin-injected rats; A LT, alanine transaminase; A ST, aspartate transaminase; G Ic 6-P, glucose 6-phosphate; SSC, saline sodium citrate. no effect was found in healthy animals. M oreover, in the liver of ST Z-diabetic rats, tungstate treatment increased glucokinase, 6-phosphofructo-2-kinase and pyruvate kinase activity and decreased phosphoenolpyruvate carboxykinase expression to almost the same levels as those measured in healthy animals. These changes led to a partial restoration of glycogen, glucose 6-phosphate and fructose-2,6-bisphosphate levels [1]. These combined changes result in a reduction of glucose production and also in an increase in glucose disposal, thus reducing hyperglycaemia. Therefore, tungstate is an efficient tool to reduce hyperglycaemia in insulin-deficient rats. We therefore examined whether tungstate could exert effects on other animal models of diabetes. We selected adult rats injected with streptozotocin during the neonatal period (nSTZ-diabetic rats), an animal model of 
non-insulin-dependent diabetes mellitus (NIDDM). In these animals mild hyperglycaemia appears between 1 and 2 months of life together with a partial deficiency in insulin. It is also known that the functional behaviour of the endocrine pancreas is characterized by a preferential impairment of the secretory response to $\mathrm{D}$-glucose as distinct from other nutrient or non-nutrient secretagogues [2-4]. In this paper we describe the effects of tungstate administered orally in this animal model, and the mechanism by which tungstate was able to normalize glycaemia in these diabetic animals.

\section{Materials and methods}

M aterials. Sodium tungstate was from Carlo E rba (M ilano, Italy) and ST Z was from Sigma (St. L ouis, M o., U SA ). E nzymes and biochemical reagents were either from $B$ oehringer $M$ annheim ( $M$ annheim, Germany) or Sigma. A II other chemicals were of analytical grade.

A nimals and experimental design. Wistar rats obtained from Charles River were allowed to breed. Diabetes was induced in new-born males by a single injection of ST Z ( $100 \mu \mathrm{g} / \mathrm{g}$ body weight) in $0.9 \% \mathrm{NaCl}$ with $100 \mathrm{mmol} / \mathrm{l}$ sodium citrate $(\mathrm{pH}$ 4.5) on their first day of life [5]. The animals were monitored for hyperglycaemia after the first month of life. The animals that became diabetic were used for the experiments when they were 9 weeks old. The STZ-injected rats that did not develop diabetes were discarded. A t the beginning of the experiment, both the diabetic animals and their healthy siblings were divided into two different groups (untreated and tungstate treated). In the first group (untreated), rats received distilled water as drinking water. The other animals (treated) were given a solution of $2 \mathrm{mg} / \mathrm{ml}$ of sodium tungstate in distilled water. The animals were kept under a constant 12-h light-dark cycle (lights on at 08.00 hours) and were allowed to eat and drink ad libitum. The treatment was carried out for 15 days. D uring this period, the fluid and food intake was measured between 10.00 and 12.00 hours; and the body weight and blood glucose (Reflotron; Boehringer Manheim) were measured every 2 days.

A the end of the treatment, rats were killed by decapitation. Immediately, blood was collected to measure serum parameters and additional blood samples were collected on EDTA. A fter centrifugation at $1000 \mathrm{~g}$ for $15 \mathrm{~min}$ at $4^{\circ} \mathrm{C}$, the plasma was removed and stored at $-20^{\circ} \mathrm{C}$. Plasma insulin was measured in $100 \mu$ l of plasma by radioimmunoassay (CIS, Bioternational, G if-Sur-Y vette, France). Livers were excised and sliced; fragments were either used immediately to measure enzyme activities or rapidly frozen in liquid $\mathrm{N}_{2}$ for later processing. For islet isolation, the pancreas was inflated with Hank's Balanced Salt Solution (H BSS) solution by cannulation of the pancreatic duct and then dissected and incubated with collagenase. When the pancreas was used for morphometry, it was dissected and immediately frozen in liquid $\mathrm{N}_{2}$ until the procedure.

A nalytical procedures in serum samples. Serum alanine transaminase $(A L T)$, aspartate transaminase (AST), urea and creatinine were measured spectrophotometrically by standard techniques adapted to a D ax 72 analyser ( $B$ ayer, B ayer D iagnostics, L everkusen, G ermany).
E nzymeassays. G lycogen synthase and phosphorylase activities were determined in fresh liver samples homogenized in 10 volumes of ice-cold $10 \mathrm{mmol} / / \mathrm{Tris} / \mathrm{H} \mathrm{Cl}$ buffer ( $\mathrm{pH}$ 7.4) containing $150 \mathrm{mmol} / \mathrm{KF}, 15 \mathrm{mmol} / \mathrm{E} \mathrm{ETA}, 0.6 \mathrm{~mol} / \mathrm{l}$ sucrose, $1 \mathrm{mmol} / \mathrm{l}$ phenylmethanesulfonyl fluoride, $1 \mathrm{mmol} / \mathrm{l}$ benzamidine, $25 \mu \mathrm{g} /$ $\mathrm{ml}$ leupeptin and $50 \mathrm{mmol} / / \beta$-mercaptoethanol. The homogenates were centrifuged at $10000 \mathrm{~g}$ for $15 \mathrm{~min}$ at $4{ }^{\circ} \mathrm{C}$ and the supernatants were used for determinations. G lycogen synthase activity ratio (-G Ic 6-P/ + G Ic 6-P) and total activity were measured as previously described [6]. G lycogen phosphorylase a activity was determined as previoulsy described [7]. G lucokinase activity was measured in fresh liver samples homogenized in 10 volumes of ice-cold $50 \mathrm{mmol} / \mathrm{l}$ Tris/ $\mathrm{HCl}$ buffer $(\mathrm{pH} 7.4)$ with $1 \mathrm{mmol} / \mathrm{l} \mathrm{EDTA}, 100 \mathrm{mmol} / \mathrm{K} \mathrm{KCl}, 300 \mathrm{mmol} / \mathrm{l}$ sucrose and $10 \mathrm{mmol} / \mathrm{l} \beta$-mercaptoethanol. The homogenates were centrifuged at $10000 \mathrm{~g}$ for $15 \mathrm{~min}$ at $4^{\circ} \mathrm{C}$. G lucokinase activity of the supernatants was determined as previously described [8].

M etabolite assays. Liver glycogen content was determined as previously described [9]. Frozen liver samples were homogenized with 10 volumes of ice-cold $30 \%(\mathrm{w} / \mathrm{v}) \mathrm{KOH}$ and heated at $100^{\circ} \mathrm{C}$ for $15 \mathrm{~min}$; glycogen was determined after ethanol precipitation and enzymatic hydrolysis to glucose. G Ic 6-P levels were determined in the neutralized perchloric extracts from frozen samples, as described previously [10].

Pancreatic islet isolation and analysis. The pancreatic islets were isolated by the collagenase method [11]. I slets were separated from the remaining exocrine tissue by handpicking under a stereomicroscope. $B$ atches of eight islets were incubated in a shaking water bath for $90 \mathrm{~min}$ at $37^{\circ} \mathrm{C}$ in $1.0 \mathrm{ml}$ bicarbonatebuffered medium containing bovine serum albumin $(5.0 \mathrm{mg} /$ $\mathrm{ml}$ ) and D-glucose at 2.8 or $16.7 \mathrm{mmol} / \mathrm{l}$. For the first $10 \mathrm{~min}$ of incubation, the vials containing the incubation medium with the islets were gassed with $\mathrm{O}_{2}: \mathrm{CO}_{2}$ (95:5). A the end of the incubation period supernatants were stored at $-20^{\circ} \mathrm{C}$ until assayed for insulin by RIA. Insulin content was measured in these islets after they were disintegrated by ultrasonic disruption at $4{ }^{\circ} \mathrm{C}$ in $0.5 \mathrm{ml}$ acid-alcohol solution (75\% (v/v) ethanol, $23.5 \%$ bi-distilled water and $1.5 \%(\mathrm{v} / \mathrm{v}) 10 \mathrm{~mol} / \mathrm{l} \mathrm{HCl}$ ), and centrifuged at $1500 \mathrm{~g}$ for $10 \mathrm{~min}$ at $4^{\circ} \mathrm{C}$, and the supernatants were kept at $-20^{\circ} \mathrm{C}$ until insulin was assayed by R IA.

Insulin mRNA. Total islet RNA was prepared from 250 islets by a modification of the Chomcszynski method [12] (R N A zol B, TEL-TEST, Friendswood, Texas, USA ) and analysed by N orthern blotting. A liquots of $20 \mu \mathrm{g}$ R NA were separated by electrophoresis on a $1 \%$ agarose- $5 \%$ formaldehyde gel and transferred to a nylon membrane ( $\mathrm{H}$ ybond $\mathrm{N}$, A mersham, UK ). M embranes were prehybridized for $1 \mathrm{~h}$ and hybridized in R apid $\mathrm{H}$ yb buffer (RPN 1636, A mersham) for $8 \mathrm{~h}$ at $65^{\circ} \mathrm{C}$ with an insulin CDNA probe (gift of G. Bell, Chicago, IIl., U SA ) labelled with ${ }^{32} \mathrm{P}$ by random priming. The blots were washed once in $2 \times$ saline sodium citrate (SSC) $0.1 \%$ SDS at room temperature and three times in decreasing concentrations $(1 \times$ to $0.1 \times)$ of SSC $0.1 \%$ SD S at $65^{\circ} \mathrm{C}$. They were then exposed to a Kodak X-A R film and an intensifying screen at $-70^{\circ} \mathrm{C}$. The resulting autoradiographs were quantified by scanning densitometry using Cue-2 (Olympus, Tokyo, Japan), and values for insulin mR NA s were normalized to the ethidium bromide-stained $28 \mathrm{~S}$ ribosomal R N A.

Morphometric analysis of the islets. Serial sections were cut from each pancreas block and immunostained for insulin using the indirect peroxidase technique. A ntisera to insulin ( $D$ ako, G löstrup, D enmark), was used at a dilution of $1 / 10$ and peroxidase conjugated anti-guinea pig (Sigma) was used as the 
Table 1. Fluid and food intake, and tungstate intake in tungstate treated or untreated diabetic and healthy rats

\begin{tabular}{lllll}
\hline & $\begin{array}{l}\text { Fluid intake } \\
\left(\mathrm{ml} \cdot \mathrm{kg}^{-1} \text { day }^{-1}\right)\end{array}$ & $\begin{array}{l}\text { Food intake } \\
\left(\mathrm{g} \cdot \mathrm{kg}^{-1} \cdot \mathrm{day}^{-1}\right)\end{array}$ & $\begin{array}{l}\text { Weight gain } \\
(\mathrm{g} / 15 \text { days })\end{array}$ & $\begin{array}{l}\text { Tungstate intake } \\
\left(\mathrm{mg}^{\mathrm{k}} \mathrm{kg}^{-1} \cdot \mathrm{day}^{-1}\right)\end{array}$ \\
\hline Healthy rats & & & & \\
$\quad$ Untreated (10) & $100 \pm 5$ & $75 \pm 4$ & $52 \pm 7$ & 0 \\
$\quad$ Treated (12) & $77 \pm 5^{\mathrm{a}}$ & $71 \pm 4$ & $41 \pm 9$ & $154 \pm 9$ \\
$\begin{array}{l}\text { Diabetic rats } \\
\text { Untreated (12) }\end{array}$ & $145 \pm 10^{\mathrm{b}}$ & & & \\
$\quad$ Treated (12) & $85 \pm 7^{\mathrm{c}}$ & $80 \pm 4$ & $36 \pm 8$ & 0 \\
\hline
\end{tabular}

R esults are expressed as the means \pm SE $M$ for the number of animals indicated in parentheses

${ }^{a} p<0.01$ compared to untreated healthy rats;

${ }^{\mathrm{b}} \mathrm{p}<0.0001$ compared to untreated healthy rats;

c $\mathrm{p}<0.0001$ compared to untreated diabetic rats;

$d p<0.05$ compared to untreated diabetic rats

second antibody. The islet surface was calculated after o-toluidine staining. Morphometry was performed using a manual optical picture image analyser (M odel M O P-01, O lympus, Tokyo, Japan) on a projected image of the histological sections of the pancreas as described previously [13].

\section{Statistical analysis}

R esults are given as the mean \pm SE $M$ for the indicated number of rats. Comparisons among the different experimental groups were carried out by unpaired Student's t-test and A NOVA. $D$ ifferences were considered statistically significant at $p<0.05$.

Results

E ffects of tungstate treatment on physical status and blood parameters U ntreated nSTZ-diabetic rats showed a mild hyperglycaemia $(7.8 \pm 0.2 \mathrm{mmol} / \mathrm{l})$ which was normalized by tungstate treatment. A fter 6 days of tungstate administration the glycaemia of these animals reached levels $(4.6 \pm 0.1 \mathrm{mmol} / \mathrm{l})$ equal to those of their healthy siblings $(4.6 \pm 0.1 \mathrm{mmol} / \mathrm{l})$, that were maintained throughout the treatment. Tungstate administration to healthy animals did not exert any significant effect on glycaemia (Fig. 1).

In nSTZ-diabetic rats, liquid consumption increased compared with untreated healthy rats (Table 1). A dministration of tungstate to diabetic rats reduced liquid intake to levels similar to those of untreated healthy rats (Table 1). O ral administration of tungstate to healthy rats slightly reduced their liquid intake (Table 1).

To ascertain whether tungstate induced hepatic or renal damage, serum catalytic concentrations of $A L T$ and $A S T$, and creatinine and urea concentrations were measured. Tungstate treatment did not induce any significant modification in these parameters, either in healthy or in diabetic animals, indicating that tungstate did not exert any appreciable toxic effect on the liver or the kidney (Table 2).

Characterization of hepatic glucose metabolism in nSTZ rats. In a previous report [1] we showed that
Table 2. E ffect of tungstate treatment on various blood parameters

\begin{tabular}{lllll}
\hline & $\begin{array}{l}\text { A LT } \\
(\mathrm{U} / \mathrm{I})\end{array}$ & $\begin{array}{l}\text { A ST } \\
(\mathrm{U} / \mathrm{l})\end{array}$ & $\begin{array}{l}\text { Creatinine } \\
(\mu \mathrm{mol} / \mathrm{l})\end{array}$ & $\begin{array}{l}\text { U rea } \\
(\mathrm{mmol} / \mathrm{l})\end{array}$ \\
\hline H ealthy rats & & & & \\
$\quad \begin{array}{l}\text { Untreated (10) } \\
\quad 84 \pm 6\end{array}$ & $151 \pm 13$ & $34 \pm 6$ & $36 \pm 6$ \\
$\quad \begin{array}{l}\text { Treated (12) } \\
68 \pm 9\end{array}$ & $125 \pm 11$ & $39 \pm 3$ & $40 \pm 4$ \\
$\begin{array}{l}\text { D iabetic rats } \\
\text { Untreated (12) }\end{array}$ & $87 \pm 11$ & $133 \pm 18$ & $42 \pm 2$ & $36 \pm 4$ \\
$\quad$ Treated (12) & $85 \pm 8$ & $110 \pm 17$ & $34 \pm 6$ & $36 \pm 4$ \\
\hline
\end{tabular}

R esults are expressed as the means \pm SE $M$ for the number of animals indicated in parentheses

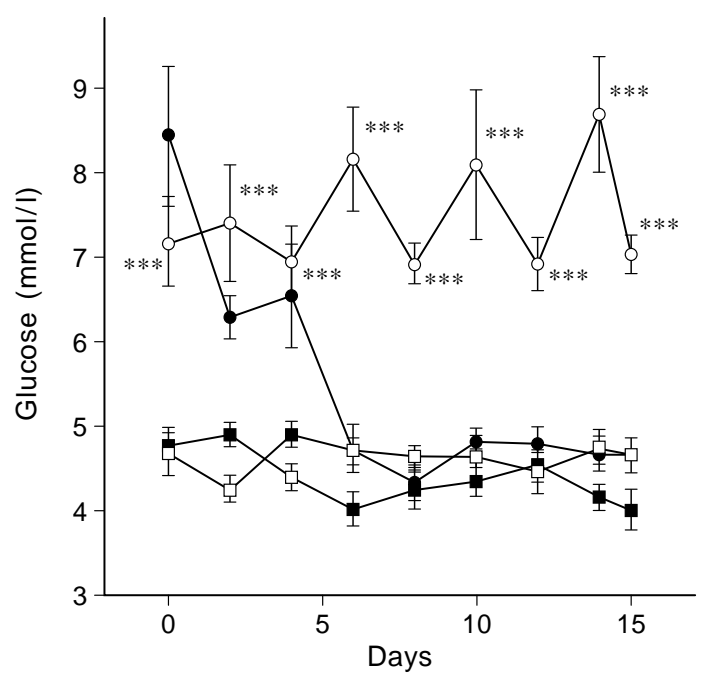

Fig. 1. E ffects of tungstate treatment on blood glucose levels in vivo. G lycaemia was measured throughout the treatment from untreated healthy $(\mathrm{HU}, \square)$, treated healthy $(\mathrm{HT}, \mathbf{\square})$, untreated diabetic (DU, O) and treated diabetic (DT, O) animals. Values are mean \pm SEM $(n=12)$. ***p $<0.0001$ compared with untreated healthy animals

in the STZ-diabetic rat hepatic glucose metabolism was markedly altered. However, hepatic glycogen levels were unchanged in untreated $\mathrm{nSTZ}$ diabetic rats (Fig. 2A ). G Ic 6-P concentration was in fact increased by about $20 \%$ in comparison to untreated healthy animals (Fig.2A). We next measured the 
A
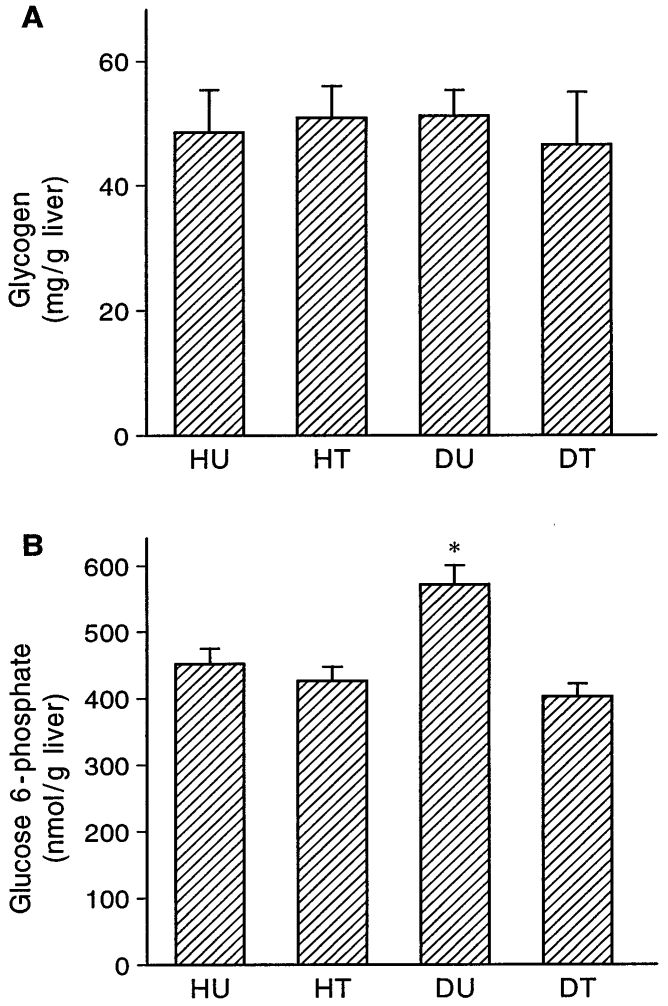

Fig. 2A , B. E ffects of tungstate treatment on hepatic glycogen and glucose 6-phosphate levels in vivo. A G lycogen level was measured in hepatic samples from untreated healthy (HU), treated healthy $(\mathrm{HT})$, untreated diabetic (DU) and treated diabetic $(D T)$ rats. Values are mean \pm SE $M \quad(n=10)$. B G lu 6-P level was measured in hepatic samples from untreated healthy $(\mathrm{HU})$, treated healthy $(\mathrm{HT})$, untreated diabetic (DU) and treated diabetic $(D T)$ rats. Values are mean \pm SE M $(n=8) . *$ $p<0.05$ compared to untreated healthy animals

activities of liver glycogen phosphorylase a and glucokinase. These two enzymes are key in the regulation of hepatic glucose metabolism, and variation in their activity may explain the increase observed in GIc 6-P. However, no significant differences were observed in glycogen phosphorylase a or glucokinase activity in nSTZ-diabetic rats when compared to healthy animals (Fig. 3). Furthermore, the total activity of glycogen synthase, the key enzyme in the control of glycogen biosynthesis, was not significantly modified in any group of animals (Table 3 ). In spite of that, diabetic rats showed an increase in the glycogen synthase (-G Ic 6-P/ + G Ic 6-P) activity ratio (Table 3 ), indicating that the enzyme was in fact in a more active state than in their heal thy counterparts.

Effect of tungstate treatment on hepatic metabolism. Tungstate did not modify hepatic glycogen concentration either in healthy or in nSTZ-diabetic rats (Fig. 2A ), although in the latter it provoked a significant decrease in the hepatic concentration of G Ic 6$P$, to the same levels observed in healthy animals.
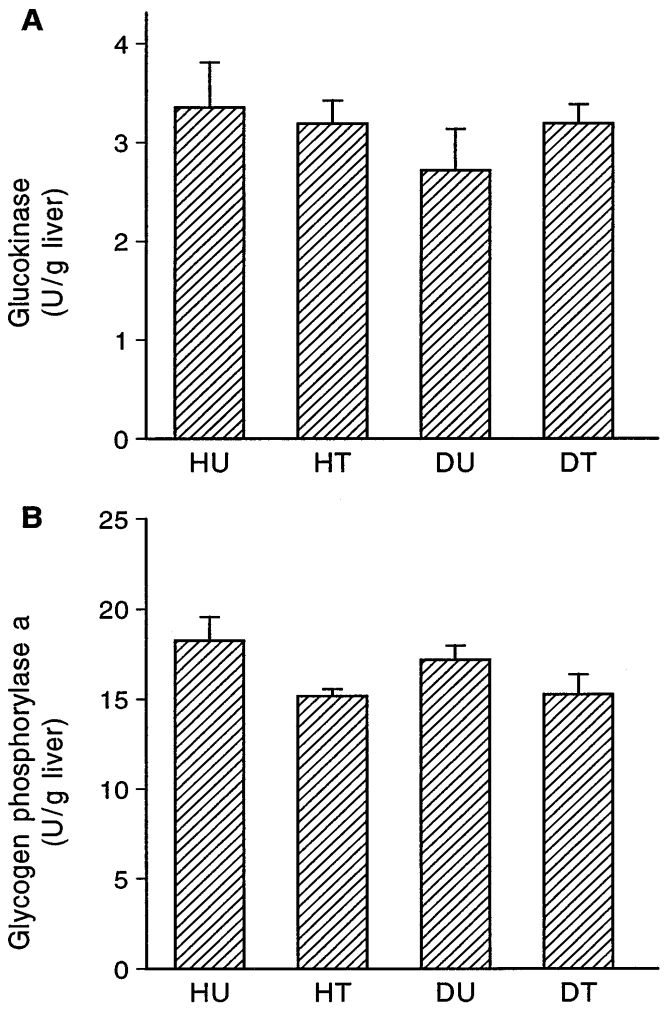

Fig. 3A , B. Effects of in vivo tungstate treatment on hepatic glucokinase and glycogen phosphorylase-activity. A Glucokinase activity was measured in hepatic samples from untreated healthy $(H U)$, treated healthy $(H T)$, untreated diabetic (DU) and treated diabetic (DT) rats. Values are mean \pm SEM $(n=12)$. B G lycogen phosphorylase a activity was measured in hepatic samples from untreated healthy $(\mathrm{HU})$, treated healthy $(H T)$, untreated diabetic (DU) and treated diabetic (DT) rats. Values are mean \pm SEM $(n=12)$

Table 3. Effect of tungstate treatment on glycogen synthase activity

\begin{tabular}{lll}
\hline & $\begin{array}{l}\text { A ctivity ratio } \\
(-G \text { Ic6P } /+G \text { Ic6P) }\end{array}$ & $\begin{array}{l}\text { Total specific activity } \\
\text { (U/g liver) }\end{array}$ \\
\hline H ealthy rats & & \\
Untreated (10) & $0.16 \pm 0.03$ & $0.39 \pm 0.04$ \\
Treated (12) & $0.17 \pm 0.02$ & $0.37 \pm 0.03$ \\
Diabetic rats & & \\
Untreated (12) & $0.22 \pm 0.03^{\mathrm{a}}$ & $0.36 \pm 0.03$ \\
Treated (12) & $0.25 \pm 0.03^{\mathrm{a}}$ & $0.38 \pm 0.04$ \\
\hline
\end{tabular}

R esults are expressed as the means $\pm \mathrm{SEM}$ for the number of animals indicated in parentheses

a $p<0.05$ compared to untreated healthy rats

Thus, the administration of tungstate normalized the concentration of hepatic G IC 6-P (Fig. 2B ). H owever, tungstate did not significantly modify $G$ Ic 6 -P concentration in healthy rats. Tungstate treatment did not alter the activity of the key enzymes of liver glycogen metabolism either in healthy or in diabetic rats (Fig.3), nor did it induce any significant variation in glycogen synthase activity ratio (Table 3 ). 
Table 4. E ffects of tungstate on islet performance

\begin{tabular}{|c|c|c|c|c|}
\hline & $\begin{array}{l}\text { G lycaemia } \\
(\mathrm{mmol} / \mathrm{l})\end{array}$ & $\begin{array}{l}\text { Insulinaemia } \\
\text { (pmol/l) }\end{array}$ & Insulin/glucose ratio & $\begin{array}{l}\text { Insulin content } \\
\text { (pmol/islet) }{ }^{\mathrm{a}}\end{array}$ \\
\hline $\begin{array}{l}\text { H ealthy rats } \\
\text { U ntreated (12) } \\
\text { Treated (12) }\end{array}$ & $\begin{array}{l}4.6 \pm 0.1 \\
4.4 \pm 0.1\end{array}$ & $\begin{array}{l}408 \pm 42 \\
\text { nd }\end{array}$ & $\begin{array}{l}88.7 \pm 25.8 \\
-\end{array}$ & $\begin{array}{l}10.8 \pm 0.7(26) \\
10.8 \pm 0.6(39)\end{array}$ \\
\hline $\begin{array}{l}\text { D iabetic rats } \\
\text { U ntreated (12) } \\
\text { Treated (12) }\end{array}$ & $\begin{array}{l}7.8 \pm 0.2^{b} \\
4.6 \pm 0.1^{c}\end{array}$ & $\begin{array}{l}330 \pm 48 \\
384 \pm 132\end{array}$ & $\begin{array}{l}42.3 \pm 4.2^{b} \\
83.5 \pm 15.0^{c}\end{array}$ & $\begin{array}{l}0.6 \pm 0.1^{b}(35) \\
3.7 \pm 0.2^{d}(28)\end{array}$ \\
\hline
\end{tabular}

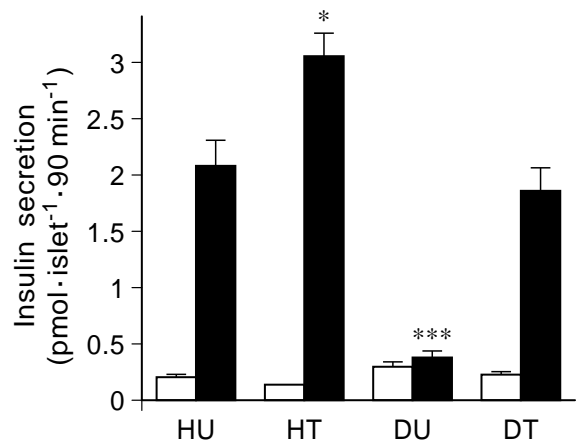

Fig. 4. Insulin secretion of the islets in tungstate treated or untreated healthy and diabetic animals. The secretion of insulin was measured in islets from untreated healthy ( $\mathrm{HU})$, treated healthy $(\mathrm{HT})$, untreated diabetic (DU) and treated diabetic (DT) rats. The experiments were performed at $2.8 \mathrm{mmol} / \mathrm{l} \mathrm{glu-}$ cose $(\square)$ and at $16.7 \mathrm{mmol} / \mathrm{l}$ glucose ( $\square$ ). The values are mean \pm SEM (4 rats, 8 islets with 12 determinations). $* p<0.01$ compared with untreated healthy animals; $* * * p<0.0001$ compared with untreated healthy animals

Effect of tungstate treatment on islet performance. Since the changes induced by tungstate in the metabolic state of the liver of the nSTZ-diabetic rats could hardly be responsible for the observed normalization of hyperglycaemia, we decided to evaluate whether tungstate treatment modified pancreatic beta-cell function, islet content or secretion. The insulin content was markedly decreased in the islets of diabetic animals (Table 4). Tungstate treatment partially restored islet insulin content in nSTZ rats to approximately $30 \%$ of that in healthy animals; however, it did not affect insulin content in healthy animals (Table 4). Moreover, preproinsulin mRNA levels also decreased in the islets of the nST Z rats to approximately $45 \%$ of that in healthy rats. This value recovered up to about $75 \%$ in treated-diabetic animals.

The beta-cell response to glucose was also analysed. A s expected, in healthy animals there was a significant increase in insulin release when the glucose concentration was shifted from 2.8 to $16.7 \mathrm{mmol} / \mathrm{l}$ (Fig.4). In contrast, the increase in insulin release evoked by $16.7 \mathrm{mmol} / \mathrm{l}$ glucose stimulus in pancreatic islets was totally abolished in islets from nSTZ rats. When islets from treated diabetic rats were stimulated with a shift in glucose concentration, an increase in insulin secretion was observed from $0.36 \pm 0.05$ to $1.83 \pm 0.21 \mathrm{pmol} \cdot$ islet $^{-1} \cdot 90 \mathrm{~min}^{-1}$. These values are similar to those observed in islets isolated from untreated healthy animals. A slight increase in insulin release was observed at $16.7 \mathrm{mmol} / /$ glucose in islets from treated healthy animals (Fig. 4). Thus, tungstate administration restored the ability of beta cells to respond to an increase in glucose concentration.

M orphological data. We next determined whether the number of beta cells and/or islet surface area was changed after the treatment. No significant differences were observed in the mean islet surface area between the experimental groups. H owever, diabetic animals had a significant decrease $(40 \%)$ in the beta-cell/exocrine tissue ratio compared with untreated healthy animals. The treatment of nSTZ-diabetic rats increased this ratio to values similar to those in healthy animals (Table 5). Tungstate administration to healthy rats did not modify the beta-cell/ exocrine tissue ratio.

\section{Discussion}

The results presented in this paper show that tungstate, administered orally, can normalize glycaemia in an animal model of NIDDM, the nSTZ-diabetic rat. In a previous report [1], we showed that tungstate is effective in reducing hyperglycaemia in STZ-diabetic rats, a model of insulin-dependent diabetes mellitus (IDD M ). Therefore, tungstate is useful as a hypoglycaemic agent in animal models of both types of diabetes. H owever, important differences have been observed regarding the mechanism by which tungstate exerts its action in each case.

In STZ-diabetic rats, the main action of tungstate appears to be the restoration of the hepatic glucose metabolism [1], by increasing the capacity of the liver to utilize glucose through glycolysis and glycogenesis. 
Table 5. M orphometric analysis of pancreatic islets

\begin{tabular}{|c|c|c|}
\hline & $\begin{array}{l}\text { B eta cell/exocrine tissue } \\
(\%)\end{array}$ & $\begin{array}{l}\text { Islet surface } \\
\left(\mu \mathrm{m}^{2}\right)^{\mathrm{a}}\end{array}$ \\
\hline $\begin{array}{l}\text { H ealthy rats } \\
\text { U ntreated (4) } \\
\text { Treated (4) }\end{array}$ & $\begin{array}{l}1.45 \pm 0.05 \\
1.35 \pm 0.15\end{array}$ & $\begin{array}{l}10897 \pm 1788(21) \\
11092 \pm 1033(20)\end{array}$ \\
\hline $\begin{array}{l}\text { D iabetic rats } \\
\text { U ntreated (4) } \\
\text { Treated (4) }\end{array}$ & $\begin{array}{l}0.86 \pm 0.07^{b} \\
1.73 \pm 0.38^{c}\end{array}$ & $\begin{array}{l}12219 \pm 1298(41) \\
10479 \pm 936(60)\end{array}$ \\
\hline
\end{tabular}

R esults are expressed as the means \pm SE M for the number of animals indicated in parentheses.

a The experiments were performed with the number of islet indicated in parentheses pooled from four animals.

${ }^{b} p<0.001$ compared to untreated healthy rats;

${ }^{c} p<0.05$ compared to untreated diabetic rats

M oreover, tungstate also decreases the hepatic potential for glucose output through reduction of the expression of the principal key enzyme in gluconeogenesis, phosphoenolpyruvate carboxykinase. H owever, this does not appear to be the case in nST Z-diabetic rats. In these animals, liver glucose metabolism is only slightly altered, and glycogen levels are not decreased, as they are in the STZ-diabetic animals. A ctivities of glucokinase and glycogen phosphorylase, key enzymes of glucose metabolism, which are decreased in the ST Z-diabetic rats, are not affected in the nST Z-diabetic animals. Surprisingly, the only two differences observed in the livers of nSTZ-diabetic rats with respect to healthy animals are increases in G Ic 6-P concentrations and in the activation state of glycogen synthase. These changes are the opposite to those observed in STZ-diabetic rats, in which these two parameters decrease. N evertheless the modifications in hepatic glucose metabolism observed can hardly be responsible for the hyperglycaemia observed in nST Z diabetic rats. Therefore, although it has been recently demonstrated [14] that liver alterations are the main cause of hyperglycaemia in STZ-rats, this is probably not the case for nST Z -diabetic rats.

Tungstate treatment of nSTZ-diabetic rats does not modify the hepatic parameters studied, although it restores G Ic 6-P levels. The normoglycaemic effect of tungstate in these animals cannot be attributed to the small changes observed in this metabolite.

The main cause of hyperglycaemia in nSTZ-diabetic rats appears to be the lack of response of betacells to a glucose stimulus. These animals can maintain normal levels of basal insulinaemia [15], whereas the response to an increase in blood glucose levels (as in the postprandial state) is probably impaired. These data correlate with the observed decrease in beta-cell insulin content and beta cell mass in the pancreas of these diabetic animals. Tungstate treatment restores the ability of beta cells to respond to glucose, and causes an increase in insulin content, and beta-cell mass. Therefore, these results suggest that tungstate may exert two different types of effect on the islets. On the one hand it may increase the sensitivity of beta cells to glucose. $\mathrm{O}$ n the other, it may raise the insulin content, probably as a result of an increase in insulin gene expression as indicated by a rise in preproinsulin mR NA levels. This effect could be caused by an increase in insulin biosynthesis by the remaining beta cells or by an increase in the beta-cell mass in the pancreas. This latter effect was observed in morphometric analysis. This trophic effect of tungstate on the beta cells could be direct or indirect. In experiments performed in islet cell lines we observed that tungstate, when added to the culture medium, increased the incorporation of $\left({ }^{3} \mathrm{H}\right)$-thymidine to these cells (unpublished data) suggesting a direct effect. Taken together, these results indicate that tungstate may exert a repairing action in the beta cells of the nST Z -diabetic rats. When healthy animals were treated with tungstate a slight increase in insulin secretion of their beta cells in response to an increase in glucose concentration was also observed. This indicates that in healthy animals tungstate can still increase sensitivity to glucose.

In summary, tungstate appears to exert its action by two different mechanisms. In ST Z-diabetic rats, it acts by normalizing liver metabolism, while in nST Z diabetic rats its main effect is exerted at pancreatic level. In both cases, an important feature is that tungstate does not cause hypoglycaemia in healthy animals. O ther insulin-like effects of tungstate have also been reported in studies "in vitro" [16, 17]. Thus, tungstate may offer the basis for a new oral treatment of both types of diabetes.

A cknowledgements. The authors would like to thank Ms. A. A drover, MS. C. Franco and MS. R. D íez for their excellent technical assistance, and Mr. R. R ycroft for his assistance in preparing the $E$ nglish manuscript. $A$. B. was recipient of a predoctoral fellowship FI/94-1.010 from the Generalitat de Catalunya. J.F.-A . was supported by "Fundació Clínici". This work was supported by grants PB91-0276 from DGICYT (to J.J.G.) and 95/0267 from FIS (to R.G.). B oth laboratories are members of the "Catalan N etwork for the Study of Experimental D iabetes", supported by grant X T 94-13 from the G eneralitat de Catalunya.

\section{References}

1. B arberà A , R odríguez-G il J E , G uinovart J J (1994) Insulinlike actions of tungstate in diabetic rats. J $\mathrm{B}$ iol Chem 269: 20047-20053

2. Giroix $M-H$, Sener A, Bailbe D, Portha B, M alaisse WJ (1990) Impairment of the mitochondrial oxidative response to D-glucose in pancreatic islets from adult rats injected with streptozotocin during the neonatal period. Diabetologia 33: 654-660

3. Portha B (1985) D ecreased glucose-induced insulin release and biosynthesis by islets of rats with non-insulin-dependent diabetes: effect of tissue culture. Endocrinology 117: 1735-1741 
4. G iroix $M-H, B$ aetens $D, R$ asschaert J, Leclercq-M eyer V, Sener A , Portha B, M alisse WJ (1992) Enzymic and metabolic anomalies in islets of diabetic rats: relationship to $B$ cell mass. Endocrinology 130: 2634-2640

5. Portha B , L evacher C, Picon L, R osselin G (1974) D iabetogenic effect of streptozotocin in the rat during the perinatal period. D iabetes 23: 880-895

6. Thomas JA , Schlender K K, Larner J (1968) A rapid filter assay for UDP glucose-glycogen-glycosyl transferase including an improved biosynthesis of UDP- ${ }^{14} \mathrm{C}$-glucose. A nal Biochem 25: 486-499

7. Gilboe DP, Larson KL, Nuttall FQ (1972) Radioactive method of the assay of glycogen phosphorylase. A nal Biochem 47: 20-27

8. N ewgard CB, H irsch LJ, Foster DW, M CG arry JD (1983) Studies on the mechanism by which exogenous glucose is converted into liver glycogen in the rat. J Biol Chem 258: 8046-8052

9. Chan TM, Exton JH (1976) A rapid method for the determination of glycogen content and radioactivity in small quantities of tissue or isolated hepatocytes. A nal Biochem 71: $96-105$

10. Lang G, M ichal G (1974) D-G lucose-6-phosphate and DFructose-6-phosphate. In: B ergmeyer H U (ed) M ethods of enzymatic analysis vol 3. A cademic press, New York, pp 1238-1242

11. Malaisse-L agae F, M alaisse WJ (1984) Insulin release by pancreatic islets. In: Larner J, Pohl SL (eds) M ethods in diabetes research vol 1. J ohn Wiley \& Sons, N ew York, pp 147-152

12. Chomcszynski P, Sacchi N (1987) Single-step method of RNA isolation by acid guanidinium thiocyanate-phenolchloroform extraction. A nal Biochem 162: 156-159

13. Clark A, Wells CA, B uley ID et al. (1988) Islet amyloid, increased A-cells, reduced B-cells and exocrine fibrosis: quantitative changes in the pancreas in type 2 diabetes. $\mathrm{Di}$ abetes R esearch 9: 151-158

14. B urcellin R, E ddouks M, M aury J, K ande J, A ssan R, G irard J (1995) Excessive glucose productions, rather than insulin resistance, accounts for hyperglycaemia in recent-onset-streptozotocin-diabetic rats. D iabetologia 38: 283-290

15. Portha B, Serradas P, Blondel O, G iroux M H, Bailbe D (1990) Relation between hyperglycaemia and impairment of insulin secretion and action. Information from n-STZ rat models. Frontiers in diabetes research. L essons from animal diabetes III Vol. V II pp 334-341

16. E Iberg G, L i J, Shechter Y (1994) Vanadium activates or inhibits receptor and non-receptor protein tyrosine kinases in cell-free experiments, depending on its oxidation state. Possible role of endogenous vanadium in controlling cellular protein tyrosine kinase activity. J Biol Chem 269: 95219527

17. Li J, Elberg G, G efel D, Shechter Y (1995) Permolybdate and pertungstate-potent stimulators of insulin effects in rat adipocytes: mechanism of action. Biochemistry 34 : 6218-6225 